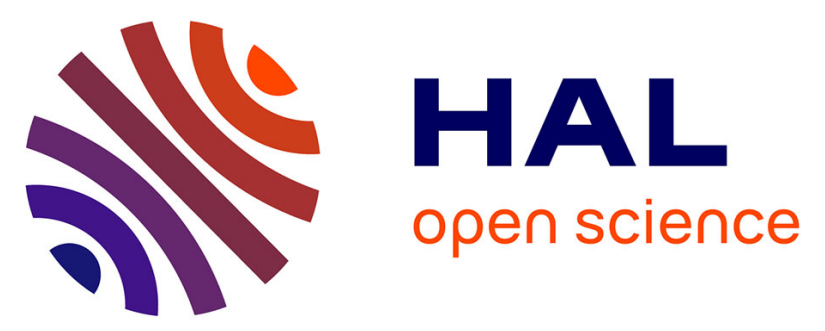

\title{
Metabolomic study of the response to cold shock in a strain of Pseudomonas syringae isolated from cloud water
}

Cyril Jousse, Céline Dalle, Isabelle Canet, Marie Lagrée, Mounir Traïka, Bernard Lyan, Cédric Mendes, Martine Sancelme, Pierre Amato, Anne-Marie

Delort

\section{To cite this version:}

Cyril Jousse, Céline Dalle, Isabelle Canet, Marie Lagrée, Mounir Traïka, et al.. Metabolomic study of the response to cold shock in a strain of Pseudomonas syringae isolated from cloud water. Metabolomics, 2018, 14 (1), 13 p. 10.1007/s11306-017-1295-7 . hal-01663290

\section{HAL Id: hal-01663290 https://hal.science/hal-01663290}

Submitted on 6 Nov 2020

HAL is a multi-disciplinary open access archive for the deposit and dissemination of scientific research documents, whether they are published or not. The documents may come from teaching and research institutions in France or abroad, or from public or private research centers.
L'archive ouverte pluridisciplinaire HAL, est destinée au dépôt et à la diffusion de documents scientifiques de niveau recherche, publiés ou non, émanant des établissements d'enseignement et de recherche français ou étrangers, des laboratoires publics ou privés.

\section{(ㅇ)(1) $\$$}

Distributed under a Creative Commons Attribution - NonCommercial - NoDerivatives 44.0 
3 Cyril Jousse ${ }^{1,3}$, Céline Dalle ${ }^{1,3}$, Isabelle Canet $^{1}$, Marie Lagrée ${ }^{1,3}$, Mounir Traïkia ${ }^{1,3}$, Bernard Lyan ${ }^{2,3}$, Cédric

4 Mendes $^{3}$, Martine Sancelme ${ }^{1}$, Pierre Amato ${ }^{1}$ and Anne-Marie Delort ${ }^{1,3} *$

5 (1) Université Clermont Auvergne - CNRS - SIGMA-Clermont, Institut de Chimie de Clermont-Ferrand, F-63000

6 Clermont-Ferrand, France

(2) Université Clermont Auvergne - INRA, UNH, F-63000 Clermont-Ferrand, France

(3) Université Clermont Auvergne - INRA, MetaboHUB / Plateforme d'exploration du métabolisme, Clermont-

9 Ferrand, France

11 Keywords: NMR, MS, cloud, peptides, metabolomics, cold stress, Pseudomonas, oxidative stress.

12

*Corresponding author e-mail address: A-Marie.DELORT@uca.fr tel +33473407714

\title{
Acknowledgments
}

This research has been supported by the ANR French program MetaboHUB. We would like to thank Mélanie Pétéra for her valuable technical assistance.

\begin{abstract}
Introduction

Active microorganisms have been recently discovered in clouds, thus demonstrating the capacity of microorganisms to exist in harsh environments, including exposure to UV and oxidants, osmotic and cold shocks, etc. It is important to understand how microorganisms respond to and survive such stresses at the metabolic level.

\section{Objectives}

The objective of this work is to assess metabolome modulation in a strain of Pseudomonas syringae isolated from cloud water and facing temperature downshift from $17{ }^{\circ} \mathrm{C}$ to $5{ }^{\circ} \mathrm{C}$ by identifying key molecules and pathways of the response/adaptation to cold shock.

Methods

Bacterial extracts from suspensions of cells grown at $17^{\circ} \mathrm{C}$ and further incubated in microcosms at $5{ }^{\circ} \mathrm{C}$ and $17{ }^{\circ} \mathrm{C}$ to mimic cloud conditions were analysed by combining LC-MS and NMR; the results were evaluated in comparison to similar suspensions kept at constant temperature. The differences in the metabolome profiles were deciphered using multivariate statistics (PLS-DA).

\section{Results}

Key cold shock biomarkers were observed, including cryoprotectants (trehalose, glucose, glycerol, carnitine, glutamate), antioxidants (glutathione and carnitine) and their precursors, alkaloids (bellendine and slaframine) and metabolites involved in energy metabolism (ATP, carbohydrates). Furthermore, new short peptides ( 9 dipeptides and a tetrapeptide) were found that have no known function.

\section{Conclusions}

This study shows that in response to cold temperatures, Pseudomonas syringae PDD-32b-74 demonstrates numerous metabolism modifications to counteract the impacts of low temperatures.
\end{abstract}

\section{Introduction}

Microorganisms have been studied in different areas of the environment including soil as well as ocean and surface waters; however, microorganisms alive in cloud water have been more recently examined (Desprès et al. 2012; Sattler et al. 2001; Bauer et al. 2002; Amato et al. 2005; Amato et al. 2007a; Ahern et al. 2007; Kourtev et al. 2011; Vaïtilingom et al. 2012; Šantl-Temkiv et al. 2013; Frölich-Nowoisky et al. 2016). Although only a fraction of the total microbial communities can be detected by cloud water cultures (Amato et al. 2007b), measurements of anabolic 
precursor incorporation rates by the biomass (Sattler et al. 2001; Vaïtilingom et al. 2011; Vaïtilingom et al. 2013) and ATP quantification (Vaïtilingom et al. 2012; Vaitilingom et al. 2013; Amato et al. 2007c; Hill et al. 2007) revealed surprisingly high level of metabolic activity. Microbial metabolic activity in clouds is thus suspected to contribute to atmospheric chemistry (Ariya and Amyot 2004; Delort et al. 2010); it also proves that microorganisms are able to survive in stressful atmospheric conditions, such as temperature changes, UV radiations, evaporation-condensation cycles, exposure to chemical mixtures with potentially toxic compounds, strong oxidants, and acidic $\mathrm{pH}$ (Deguillaume et al. 2014). A recent study by Joly et al. (2015) suggested that the greatest stresses encountered in the atmosphere by microorganisms are freeze/thaw and condensation/evaporation cycles, both of which are generally linked with cloud temperature shifts.

At low temperatures, global cellular functioning is generally altered due to decreased molecular diffusion and reaction rates as well as the rigidification of macromolecules and membranes. Various well-known responses in microorganisms include the production or uptake of compatible solutes (e.g., Welsh 2000), modifications of the lipid composition of membranes, production of chaperones and modified enzymes capable of functioning in the cold (e.g., Feller and Gerday 2003), and adaptation of energy metabolism (e.g., Amato and Christner 2009). To better understand how bacteria globally respond to such temperature shifts and resist atmospheric stresses, the response of Pseudomonas syringae PDD-32b-74 to a cold shock was examined in this study. The choice of Pseudomonas syringae 32b-74 as model strain is based on the abundance of Pseudomonas species in clouds at Puy de Dôme (Vaïtilingom et al. 2012), in particular, P. syringae, and their capacity to be involved in atmospheric chemical (Amato et al. 2007c) and physical processes (Attard et al. 2012; Joly et al. 2013; Amato et al. 2015; Renard et al. 2016). Pseudomonas syringae $32 \mathrm{~b}-74$ is also of particular interest as it has a very efficient ice nucleation activity, which could be advantageous to resist cold shocks (Joly et al. 2013). To study the impact of temperature on its metabolome, a metabolomic approach combining LC-MS and NMR was used. Although it is still scarcely applied in the field of environmental microbiology, metabolomics was shown to be a powerful tool to investigate the influence of temperature changes on microbial metabolomes (Coucheney et al. 2008; Boroujerdi et al. 2009; Boroujerdi et al. 2012; Singh et al. 2011; Ye et al. 2012; Jozefczuk et al. 2010; Miranda et al. 2013; Azizan et al. 2012; Alreshidi et al. 2015).

\section{Materials and Methods}

Chemicals, reagents, standard solutions, sample preparations, and details on analytics (NMR, MS and statistics) are fully described in the supplementary material. A general outlook of the experimental design used for conducting the metabolomics experiment is also presented in the supplementary material (Figure S1).

\subsection{Microbial incubation and metabolite extraction} originally isolated from cloud water sampled at the puy de Dôme summit $(1465 \mathrm{~m}$ ) in November 2009 (Vaitilingom et al. 2012). First, the bacteria were cultured on agar plates (12 biological replicates) at $17^{\circ} \mathrm{C}$ (Figure S1, I).

Second, bacteria collected from the plates were transferred in an aqueous medium (water) to mimic cloud water and incubated for 14 hours at either $5{ }^{\circ} \mathrm{C}$ or $17{ }^{\circ} \mathrm{C}$ (Figure S1, II). The two temperatures were chosen according to the average temperatures measured at the puy de Dôme summit where cloud water is sampled during winter $\left(5^{\circ} \mathrm{C}\right)$ and summer $\left(17^{\circ} \mathrm{C}\right)$. In this way, two typical atmospheric scenarios can be mimicked. At the end of incubation in the aqueous medium, the cell pellets were centrifuged and rinsed twice with sterile water. The metabolomes of the 24 bacterial pellets were extracted with $600 \mu \mathrm{L}$ of a cold ternary solvent $\left[\mathrm{H}_{2} \mathrm{O}: \mathrm{MeOH}: \mathrm{CH}_{3} \mathrm{CN}, 1: 2: 2\right.$; (Lin et al. 2007; Rabinowitz \& Kimball 2007; Shin et al. 2010)]. Finally, 12 extracts of $600 \mu \mathrm{L}$ were obtained for each incubation temperature $\left(5^{\circ} \mathrm{C}\right.$ and $\left.17{ }^{\circ} \mathrm{C}\right)$. These extracts were treated for NMR or MS analyses (Figure S1, IV).

\subsection{LC-MS and LC-MS-MS analyses (figure S1, IV and SM-§2)}

\section{UPLC-MS analyses for profiling}

Seventy-two profiles ( 3 × $20 \mu \mathrm{L}$ aliquots of each extract) were analysed using the Metabolic profiler® platform (Bruker). Briefly, a fast LC system (Agilent 1200 series) was equipped with an Acquity HSST3 C18 column (50 x

$1012.1 \mathrm{~mm}, 1.8 \mu \mathrm{m}$; Waters) and coupled to a MicroToF mass spectrometer in positive electrospray ionization mode (50-

$1021000 \mathrm{~m} / \mathrm{z} ;$ Bruker). 
UPLC-MS/MS analyses for structural identification

A few samples that were representative for the features in the statistical model (PLS-DA) were analysed in full scan mode and MS/MS on an LTQ Orbitrap Velos MS (ThermoFisher Scientific) with similar chromatographic conditions (gradient, column) as for profiling.

\subsection{NMR analyses (figure $S 1, I V$ and $S M-\S 3$ )}

\section{ID on flow NMR analyses for profiling}

Twenty-four one-dimensional ${ }^{1} \mathrm{H}$ NMR noesygpprld experiments (i.e., profiles) were done on a Metabolic Profiler ${ }^{\circledR}$ equipped with an Avance III $500 \mathrm{MHz}$ NMR spectrometer using a $3 \mathrm{~mm}$ FISEI z-gradient $\left({ }^{1} \mathrm{H}-{ }^{13} \mathrm{C}\right)$ probe with a 60 $\mu \mathrm{L}$ flow cell (Bruker).

\section{D and 2D NMR analyses for structural identification}

The NMR spectrometer was an Avance $500 \mathrm{MHz}$ equipped with a 5-mm inverse-triple tuned (TXI) ${ }^{1} \mathrm{H} / 1^{3} \mathrm{C} /{ }^{15} \mathrm{~N}$ with z-gradient coil probe (Bruker). One-dimensional ${ }^{1} \mathrm{H}$-Spectra and 2D homonuclear $\left({ }^{1} \mathrm{H}-{ }^{1} \mathrm{H}\right.$ COSY,${ }^{1} \mathrm{H}-{ }^{1} \mathrm{H}$ TOCSY, ${ }^{1} \mathrm{H}$ ${ }^{1} \mathrm{H}$ JRES $)$ and heteronuclear $\left({ }^{1} \mathrm{H}-{ }^{13} \mathrm{C}\right.$ HSQC $)$ experiments were performed for structural identification.

\subsection{Data analyses $(\mathrm{SM}-\S 4 \& 5)$}

\section{MS and NMR data treatments}

The MS raw data were exported using NetCDF format and extracted with the XCMS package (Smith et al. 2006) in the R environment (version 2.15.3). Quadratic correction of the retention time was performed to consider the chromatography time shift evolution in the analytical experiments. In-source fragmentation and adducts were screened using CAMERA package (in the $\mathrm{R}$ environment; Kuhl et al. 2012) in order to reduce information redundancy.

One-dimensional ${ }^{1} \mathrm{H}-\mathrm{NMR}$ spectra were divided into $0.001 \mathrm{ppm}$ wide buckets after reduction over the chemical range of -0.5 to $10 \mathrm{ppm}$ and considering the exclusion area around the residual water signal (4.6 to $5.1 \mathrm{ppm}$ ), using AMIX software (Bruker). The signal intensity in each bucket was integrated using the sum of the intensities mode, and the spectra were scaled to total intensity.

\section{Statistical analyses}

One matrix per analytical device [ESI(+)/MS or $\left.{ }^{1} \mathrm{H}-\mathrm{NMR}\right]$ was built and subjected to multivariate analyses (SIMCAP v. 12, Umetrics). Principal component analyses (PCA) were conducted to check the population homogeneity and detect possible outliers. A supplementary variable ("Y matrix") corresponding to the two classes of bacteria populations (exposed and not exposed to cold shock; Figures S2 and S3) was considered for the Partial Least Squares (PLS) regression analyses.

\section{Databases}

Identification was completed using the metabolite and pathways databases [KEGG (Kanehisa and Goto 2000), MetaCyc (Caspi et al. 2014), HMDB (Wishart et al. 2013), and METLIN (Smith et al. 2005)] as well as relevant publications (Nicholson et al. 1995; Fan 1996). MS/MS fragmentation patterns were compared to simulations with the Massfrontier (v.7; Thermo Scientific) software.

\section{$144 \quad 3.1$ Identification of cold shock biomarkers in Pseudomonas syringae 32b-74}

Figure 1a presents the PLS-DA analysis performed with 72 samples based on the LC-MS analysis. The two populations corresponding to the bacterial suspensions incubated at $17{ }^{\circ} \mathrm{C}$ and $5{ }^{\circ} \mathrm{C}$ are clearly separated. Using the two first components, $62 \%$ of the variability explanation was obtained. One outlier sample was removed from the MS data. A list of 118 ion discriminating cells incubated at the 2 temperatures was obtained to compose the VIP list. Thirty-five ions were identified due to their exact mass and fragmentation pattern (validated by complementary Orbitrap experiments), the use of reference samples or by a validation based on their detection by NMR (Table 1). The detailed list of the masses and retention times of the identified metabolites is given in the supplementary data (Table S2).

Figure $1 \mathrm{~b}$ shows the PLS-DA analysis performed with the results from 24 samples based on $1 \mathrm{D}{ }^{1} \mathrm{H}$ NMR 
experiments; the two populations corresponding to the bacterial suspensions incubated at $17{ }^{\circ} \mathrm{C}$ or at $5{ }^{\circ} \mathrm{C}$ are clearly discriminating buckets was obtained to compose the VIP list; 21 metabolites (including two glucose isomers) were identified as biomarkers. Their identification was validated by confirmation of their structure by 2-D NMR spectra $\left({ }^{1} \mathrm{H}-{ }^{1} \mathrm{H}\right.$ JRES, ${ }^{1} \mathrm{H}-{ }^{1} \mathrm{H}$ COSY, ${ }^{1} \mathrm{H}-{ }^{1} \mathrm{H}$ TOCSY, ${ }^{1} \mathrm{H}-{ }^{13} \mathrm{C}$ HSQC) or by a validation due to MS information (Table 1 ). The detailed list of the ${ }^{1} \mathrm{H}$ and ${ }^{13} \mathrm{C}$ chemical shifts as well as the multiplicity and coupling constants of the identified metabolites are given in the supplementary data (Table S3).

Table 2 reports the VIP values of the metabolites of interest as well as the ratio of relative intensities of a given metabolite in cells incubated at $5{ }^{\circ} \mathrm{C}$ with respect to cells incubated at $17{ }^{\circ} \mathrm{C}$, termed the stressed/reference $(\mathrm{S} / \mathrm{R})$ ratio. The identification metrics proposed by Sumner et al. $(2007,2014)$ are used in this paper to assign an identification score to each metabolite (as explained in SM- $\$ 5$ and Table S1).

The comparison of the data presented in Table 2 clearly shows the complementarity nature of MS and NMR. On one hand, all the peptides, most lipids and amines, as well as some specific compounds [phosphoric acid, slaframine, gyromitrin, sarcosine, bellendine, 5'-desoxy-5'-(methylthio)adenosine] were only detected by LC-MS. On the other hand, NMR was very useful to detect sugars and other metabolites such as valine, tyrosine and glycine, glycerol, Ophosphocholine, ATP, acetate and lactate that could not be detected by MS.

Finally, it is worth noting that when molecules were detected by both techniques, the S/R ratios derived from MS and NMR were very consistent; common amino acids (Leu/Ile, Ala, Lys, Phe) and amines (putrescine) were decreasing under cold shock while AMP and glutathione concentrations were increasing.

Other analytical techniques could use complementary information such as GC-MS and FT-ICR/FT-MS.

The detailed evolutions of the metabolite concentrations are fully described in the next section in relation to their role in maintaining vital functions facing cold stress.

\subsection{Pseudomonas syringae PDD-32b-74 adapts its metabolism to maintain vital functions facing cold stress}

From the list of the biomarkers identified in Table 2 and referring to the KEGG databases and tools, the metabolic pathways impacted by the cold shock imposed to Pseudomonas syringae PDD-32b-74 (see Figure 2 and 3) are deciphered. The metabolites that are over-produced at $5{ }^{\circ} \mathrm{C}$ are indicated in yellow, while those that are underproduced are indicated in blue; putative important metabolic intermediates not detected among the VIP ions are indicated in white. The modulation of these metabolite concentrations reflects the adaptation of Pseudomonas syringae PDD-32b-74 metabolism to maintain vital functions while facing cold stress.

Energy metabolism: At low temperatures, enzymatic activities and molecular diffusion are slowed down. To maintain metabolic activity compatible with survival, some bacteria adjust their energy metabolism for increasing ATP concentration notably (Amato and Christner 2009). As a consequence, a net increase of the energetic pool constituted by AMP, ATP and Pi are observed when P. syringae PDD-32b-74 is exposed to cold shock (Figure 2). This could result from the activation of carbohydrate metabolism and of the Krebs cycle as the glucose and trehalose concentrations increased under cold conditions resulting from the degradation of glycogen.

The decrease of acetic and lactic acid concentrations (Figure 2) might be consistent with the stimulation of respiration pathways and a slowdown of the fermentation metabolism. The decrease could also result from increased utilization. For example, a cold-adapted Propionibacterium species was shown to switch from aerobiose to anaerobiose when exposed to cold temperatures with the increased lactate uptake due to overexpression of the lactate dehydrogenase (Sardesai and Babu 2000). Proteomic studies of Proteobacteria species (Rhizobium, and Psychrobacter) exposed to cold shock also revealed overexpression of this enzyme (Bakermans et al. 2007; Dalmasso et al. 2012).

Membrane fluidity: When subjected to cold, bacteria have to deal with a very important issue: the rigidification of their membrane. They need to re-establish membrane fluidity by adjusting the lipid composition to maintain vital functions such as the proton motive force and other ion exchange processes. For instance, some bacteria modify the balance phosphatidylcholine (PC) vs. phosphatidylethanolamine (PE; Fajardo et al. 2011) or increase the concentration of unsaturated fatty acids (Arvizu-Gomez et al. 2013). In this case, lipid metabolism (Figure 2) was globally slowed down as shown by the decrease of oleic and palmitoleic acid concentration (fatty acid metabolism) and of the derivatives of phosphocholine and phosphoethanolamine (glycerophospholipid metabolism). However, more lipid composition data would be needed to conclude the adjustment of membrane fluidity. In the future, more specific extraction methods should be used to better characterize the lipid fraction. 
Protection against ROS (Reactive Oxygen Species): Glutathione was clearly at higher concentration at $5{ }^{\circ} \mathrm{C}$ as well as other metabolites closely linked with it, including glutamate, glycine and 5'-desoxy 5'-methylthio(adenosine) [analogue of 5'- methylthio(adenosine); Figure 3]. Glutathione is a tripeptide composed of glutamate, cysteine and glycine; the increased glutathione concentration at low temperature is consistent with the concomitant increase of glutamate and glycine concentrations. In parallel, carnitine concentration was also increased at $5{ }^{\circ} \mathrm{C}$ (Figure 3 ). Glutathione and carnitine are well known key metabolites involved in oxidative stress metabolism (Davies 2000). Many papers report a close relationship between cold stress and oxidative stress in bacteria. It was shown that the production of free radicals $\left(\mathrm{O}_{2}{ }^{\circ-}\right.$ and $\left.{ }^{\circ} \mathrm{OH}\right)$ and $\mathrm{H}_{2} \mathrm{O}_{2}$ is increased when the temperature is decreased (Zhang et al. 2012). As a result, bacteria can increase the amount of detoxifying enzymes such as superoxide dismutase and catalase for preventing the formation of radicals, or they can produce antioxidant compounds for reducing ROS concentrations. Zhang et al. (2012) recently showed that GSH improves the resistance of Lactobacillus sanfranciscensis to cold shock. Additionally, Arvizu et al. (2013) showed the induction of a gene encoding for catalase in Pseudomonas syringae pv phaesicola when the temperature was decreased. In their metabolomic studies, Singh et al. (2011) and Ye at al. (2012) suggested that the oxidative stress pathways could be impacted by temperature shifts in L. monocytogenes and E. coli. In this study, the activation of the oxidative stress metabolism in Pseudomonas syringae PDD-32b-74 is consistent with its high survival capacity under UV exposure and high concentration of $\mathrm{H}_{2} \mathrm{O}_{2}$ (Joly et al. 2015).

Synthesis of cryoprotectants: To avoid disruptive freezing and maintain intracellular osmotic pressure, bacteria synthesize small weight molecules called "cryoprotectants" or "compatible solutes" (e.g., polyols, polyamines, carbohydrates and amino acids derivatives; see Shivaji and Prakash 2010). The most common cryoprotectants found in bacteria are trehalose, glycine, betaine, glycerol and carnitine. These cryoprotectants are supposed to act as "chemical chaperones" that prevent the denaturation and aggregation of proteins. In the case of Pseudomonas syringae PDD-32b-74, we observed the accumulation of carbohydrates such as trehalose and glucose, amines such as carnitine and amino acids such as glutamate and glycine, and glycerol (Figure 2 and 3). The same cryoprotectants were found in metabolomic studies namely, trehalose, glucose, glycerol, glycine, carnitine and glutamate in the psychrotolerant Listeria monocytogenes (Singh et al. 2011) and glycine in a Staphylococcus aureus strain exposed to cold conditions (Alreshidi et al. 2015). Trehalose has already been reported as a cryoprotectant in other Pseudomonas, in particular in different strains isolated from the rhizosphere of Himalayan plants (Bisht et al. 2013). Glutamate and trehalose were shown to accumulate in Pseudomonas syringae when subjected to osmotic stress (Kurz et al. 2010).

Alkaloid synthesis: Cold shock impacted the number of metabolites that are interconnected within the degradation pathways of ornithine and lysine, including the unexpected alkaloids, bellendine and slaframine (Figure 3). Bellendine was found at higher concentration in the cold condition; however, slaframine was present at lower concentration. Bellendine has been described in plants while slaframin is a mycotoxin. Interestingly, in a metabolomic study, slaframine concentration was shown to vary when the fungal plant pathogen Rhizoctonia solani was grown in pure cultures or in dual-cultures with the mycoparasite Stachybotrys elegans (Chamoun et al. 2015). It is worth noting that Pseudomonas syringae is from the phyllosphere, and some species can be plant pathogens related to the presence of these alkaloids; although, they have not been described in such bacteria.

Peptide synthesis: The most striking result issued from this metabolomic study is the evidence of concentration changes of specific short peptides ( 9 dipeptides and 1 tetrapeptide; Figure 2). Mass spectra analysis shows that these peptides are linear, and their low number and specific composition exclude random protein degradation. Interestingly, a parallel concentration change of the amino acids is present in these peptides. For instance, the concentration of Ala-leu, Leu-Leu, Ala-Arg, Glu-Ala, Pro-Phe, Pro-Ile, Leu-Phe and Val-Val were decreasing at the same time as that of Ala, Leu, Ile, Val and Phe. In contrast, the dipeptide Ser-Val and the tetrapeptide Gln-Ser-AlaGln were overproduced. A common amino acid to these two peptides is Serine; although, it could not be identified as free in this dataset, and the synthesis of this amino acid is achieved from phosphoglyceric acid simultaneously as the synthesis of glycine (Figure 2 and 3). Additionally, glutamine (a putative compound), which is present in the tetrapeptide, is directly linked to glutamate that is also overproduced.

This is the first clear report of such peptides as cold shock biomarkers; in addition, the presence of such linear short peptides was unexpected, as they have never been described before in Pseudomonas species. Nonlinear dipeptides have been described in Pseudomonas strains, and some cyclic dipeptides are involved in the regulation of quorum sensing (Degrassi et al. 2002); others such as NAGGN: N-AcethylGlutaminylGlutamine amide were shown to be 
synthesized in response to osmotic stress (Smith and Smith 1989; Sagot et al. 2010). However, it is unlikely that all these nonlinear dipeptides play the same role as the linear peptides detected in this study. The presence of linear short peptides has only been reported in a few cases when bacteria are facing osmotic stresses. Using a metabolomic approach, Kol et al. (2010) showed an upregulation of one dipeptide (Gly-Pro) and four tripeptides (Arg-Gly-Pro, Lys-Gly-Pro, Glu-Gly-Pro and Ala-Gly-Pro), and in response to salt shock in Steptomyces coelicolor, these peptides contained proline. The presence of short and linear proline-containing peptides has also been reported in other microbial strains facing osmotic shocks, including Listeria monocytogenes (Amezaga et al. 1995), Lactobacillus casei (Piuri et al. 2003), Oenococcus oeni (Le Marrec et al. 2007) and Bacillus subtilis (Zaprasis et al. 2013). The intracellular accumulation of these proline-containing peptides is consistent with the known role of proline as an osmoprotectant, which is obtained after peptide hydrolysis. However, these peptides may also have regulatory functions, which are not yet understood, as observed in Oenococcus oeni (Le Marrec et al. 2007).

In this case, the function of the peptides over- or underproduced under cold shock remains to be discovered.

\section{Relative importance of the resistant mechanisms to cold shock in Pseudomonas syringae:}

The previous results show that many resistance mechanisms to cold shock are present in this strain. The VIP score values (Table 2) can be used to determine which mechanisms are the most important as these scores reflect the relative importance of each metabolite to discriminate the two temperatures. The higher the VIP value, the more discriminant it is. Based on the VIP score histograms from the MS and NMR results (Figure S4), three signal groups have been highlighted. The metabolites which present the highest VIP scores (group 1) are glutathione, trehalose, palmitoleic acid and (iso)Leucine (Table 2). The second group contains some amines and amino acids (piperidine, lysine and phenylalanine) and some dipeptides (Ala-Leu, Leu-Leu); the other metabolites are in the third group.

These results suggest that the most important resistance mechanisms to this temperature change are the protection against oxidative stress (glutathione), the production of osmo/cryoprotectants (trehalose), and the adaptation of the membrane composition (Lipids). This result is consistent with the SEED subsystems annotated in the genome sequence of this strain that was recently published (Besaury et al 2017). From 181 SEED subsystems affiliated to stress response, the majority were assigned to the responses to oxidative stress (79), osmotic stress (32) and cold shock (5).

\section{Conclusions}

This is the first study reporting the metabolic response of a cloud bacterium to a cold shock, which is important to the survival of bacteria in the atmosphere. The use of combined MS and NMR helped identify a number of biomarkers and specify the metabolic routes potentially impacted by this stress. Pseudomonas syringae PDD-32b-74 could efficiently adapt its metabolism to re-establish some of its essential functions. It synthesized cryoprotectants (trehalose, glutamate, carnitine and glycine) to maintain cellular structural and functional integrity. These cryoprotectants could also act as osmoprotectants, which are also potentially important for survival in the atmosphere. In clouds, bacteria are subjected to evaporation-condensation cycles inducing important osmotic variations in cloud droplets. As a response to temperature shifts, P. syringae PDD-32b-74 is also reacted by activating the metabolic route of glutathione. This indicates the high potential of this strain to protect against ROS. Finally we showed the presence of unexpected peptides which synthetic pathways were impacted. The function of these peptides remains unknown; however, new directions of research are introduced in the adaptation of microorganisms to temperature changes and their general metabolic functioning. This study showed that $P$. syringae 32b-74 has a great potential to survive in clouds; it can adapt not only to cold stress but also to osmotic and oxidative stresses. These stresses are actually concomitant in the atmosphere and might be related to the preponderance of the genus Pseudomonas in clouds.

\section{References}

Ahern, H. E., Walsh, K. A., Hill, T. C. J., Moffett, B. F. (2007). Fluorescent pseudomonads isolated from Hebridean cloud and rain water produce biosurfactants but do not cause ice nucleation. Biogeosciences, 4, 115-124.

Alreshidi, M. M., Dunstan, R. H., Macdonald, M. M., Smith, N. D., Gottfries, J., Roberts, T. K. (2015). Metabolomic and proteomic responses of Staphylococcus aureus to prolonged cold stress. Journal of Proteomics, 121, 44-55.

Amato, P., Ménager, M., Sancelme, M., Laj, P., Mailhot, G., Delort, A.-M. (2005). Microbial population in cloud water at the Puy de Dôme: Implications for the chemistry of clouds. Atmospheric Environment, 39, 4143-4153. 
Amato, P., Parazols, M., Sancelme, M., Laj, P., Mailhot, G., Delort, A.-M. (2007a). Microorganisms isolated from the water phase of tropospheric clouds at the Puy de Dôme: major groups and growth abilities at low temperatures. FEMS Microbiology Ecology, 59, 242-254.

Amato, P., Demeer, F., Melaouhi, A., Fontanella, S., Martin-Biesse, A.-S., Sancelme, M., et al. (2007b). A fate for organic acids, formaldehyde and methanol in cloud water: their biotransformation by microorganisms. Atmospheric Chemistry and Physics, 7, 4159-4169.

Amato, P., Parazols, M., Sancelme, M., Mailhot, G., Laj, P., Delort, A.-M. (2007c). An important oceanic source of micro-organisms for cloud water at the Puy de Dôme (France). Atmospheric Environment, 41, 8253-8263.

Amato, P., Christner, B. C. (2009). Energy Metabolism Response to Low-Temperature and Frozen Conditions in Psychrobacter cryohalolentis. Applied and Environmental Microbiology, doi:10.1128/ AEM.02193-08

Amato, P., Joly, M., Schaupp, C., Attard, E., Moehler, O., Morris, C. E., et al. (2015). Survival and ice nucleation activity of bacteria as aerosol in a cloud simulation chamber. Atmospheric Chemistry and Physics, doi:10.5194/acp15-1-2015

Amezaga, M.-R., Davidson, I., McLaggan, D., Verheul, A., Abee, T., Booth, I. R. (1995). The role of peptide metabolism in the growth of Listeria monocytogenes ATCC 23074 at high osmolarity. Microbiology, doi:10.1099/00221287-141-1-41

Ariya, P. A., \& Amyot, M. (2004). New directions: The role of bioaerosols in atmospheric chemistry and physics. Atmospheric Environment, 38, 1231-1232.

Arvizu-Gomez, J. L., Hernadez-Morales, A., Agilar, J. R. P., Alavrez-Morales, A. (2013). Transcriptional profile of P. syringae pv phaesicola NPS3121 at low temperature: physiology of phytopathogenic bacteria. BMC microbiology, doi:10.1186/1471-2180-13-81

Attard, E., Yang, H., Delort, A.-M., Amato, P., Pöschl, U., Glaux, C., et al. (2012). Effects of atmospheric conditions on ice nucleation activity of Pseudomonas. Atmospheric Chemistry and Physics, 12, 10667-10677.

Azizan, K. A., Baharum, S. N., Mohd Noor, N. (2012). Metabolic profiling of Lactococcus lactis under different culture conditions. Molecules, 17, 8022-8036.

Bakermans, C., Tollaksen, S. L., Giometti, C. S., Wilkerson, C., Tiedje, J. M., Thomashow, M. F. (2007). Proteomic analysis of Psychrobacter cryohalolentis K5 during growth at subzero temperatures. Extremophiles, doi:10.1007/ s00792-006-0042-1

Bauer, H., Kasper-Giebl, A., Löflund, M., Giebl, H., Hitzenberger, R., Zibuschka, F., Puxbaum, H. (2002). The contribution of bacterial and fungal spores to the organic carbon content of cloud water, precipitation and aerosols. Atmospheric Research, 64, 109-119.

Besaury, L., Amato, P., Sancelme, M., Delort, A.-M. (2017). Draft genome sequence of Pseudomonas syringae PDD-32b-74, a model strain for ice-nucleation studies in the atmosphere. Genome Announcement 5:e00742-17. https://doi.org/10.1128/genomeA.00742-17.

Bisht, S. C., Joshi, G. K., Haque, S., Mishra, P. K. (2013). Cryotolerance strategies of Pseudomonads isolated from the rhizosphere of Himalayan plants. Springer Plus, doi:10.1186/ 2193-1801-2-667

Boroujerdi, A. F., Vizcaino, M. I., Meyers, A., Pollock, E. C., Huynh, S. L., Schock, T. B., et al. (2009). NMR-based microbial metabolomics and the temperature-dependent coral pathogen Vibrio coralliilyticus. Environmental Science and Technology, 15, 7658-7664.

Boroujerdi, A. F., Jones, S. S., Bearden, D. W. (2012). NMR analysis of metabolic responses to extreme conditions of the temperature-dependent coral pathogen Vibrio coralliilyticus. Letters in Applied Microbiology, 54, 209-216.

Caspi, R., Altman, T., Billington, R., Dreher, K., Foerster, H., Fulcher, C. A., et al. (2014). The MetaCyc database of metabolic pathways and enzymes and the BioCyc collection of Pathway/Genome Databases. Nucleic Acids Research, 42(D1), D459-D471.

Chamoun, R., Aliferis, K. A., Jabaji, S. (2015). Identification of signatory secondary metabolites during mycoparasitism of Rhizoctonia solani by Stachybotrys elegans. Frontiers in Microbiology, doi:10.3389/fmicb.2015.00353

Coucheney, E., Daniell, T. J., Chenu, C., Nunan, N. (2008). Gas chromatographic metabolic profiling: a sensitive tool for functional microbial ecology. Journal of Microbiological Methods, 75, 491-500.

Dalmasso, M., Aubert, J., Briard-Bion, V., Chuat, V., Deutsch, S.-M., Even, S., et al. (2012). A Temporal -omic Study of Propionibacterium freudenreichii CIRM-BIA1T Adaptation Strategies in Conditions Mimicking Cheese Ripening in the Cold, PLoS One, doi:10.1371/journal.pone.0029083

Davies, K. J. A. (2000). Oxidative stress, antioxidant defenses, and damage removal, repair, and replacement systems. IUBMB Life, 50, 279-289. 
Degrassi, G., Aguilar, C., Bosco, M., Zahariev, S., Pongor, S., Venturi, V. (2002). Plant growth-promoting Pseudomonas putida WCS358 produces and secretes cyclid dipetides: cross talk with quorum sensing bacterial sensors. Current Microbiology, 45, 250-254.

Deguillaume, L., Charbouillot, T., Joly, M., Vaïtilingom, M., Parazols, M., Marinoni, A., et al. (2014). Classification of clouds sampled at the puy de Dôme (France) based on $10 \mathrm{yr}$ of monitoring of their physicochemical properties. Atmospheric Chemistry and Physics, 14, 1485-1506.

Delort, A.-M., Vaïtilingom, M., Amato, P., Sancelme, M., Parazols, M., Laj, P., et al. (2010). A short overview of the microbial population in clouds: potential roles in atmospheric chemistry and nucleation processes. Atmospheric Research, 98, 249-260.

Després, V. R., Huffman, J. A., Burrows, S. M., Hoose, C., Safatov, A. S., Buryak, G., et al. (2012). Primary biological particles in the atmosphere: a review. Tellus $B, 64,1-58$.

Fajardo, V. A., McMeekin, L., LeBlanc, P. J. (2011). Influence of Phospholipid Species on Membrane Fluidity: A Meta-analysis for a Novel Phospholipid Fluidity Index. The Journal of Membrane Biology, 244, 97-10.

Fan, W.-M. (1996). Metabolite profiling by one-and two-dimensional NMR analysis of complex mixtures. Progress in Nuclear Magnetic Resonance Spectroscopy, 28, 161-219.

Feller, G., Gerday, C. (2003). Psychrophilic enzymes: hot topics in cold adaptation. Nature Reviews Microbiology, doi:10.1038/nrmicro773

Fröhlich-Nowoisky, J., Kampf, C. J., Weber, B., Huffman, J. A., Pöhlker, C., Andreae, M. O., et al. (2016). Bioaerosols in the Earth system: Climate, health, and ecosystem interactions. Atmospheric Research, 182, 346-376.

Hill, K. A., Shepson, P. B., Galbavy, E. S., Anastasio, C., Kourtev, P. S., Konopka, A., Stirm, B. H. (2007). Processing of atmospheric nitrogen by clouds above a forest environment. Journal of Geophysical Research, doi:10.1029/2006JD008002

Joly, M., Attard, E., Sancelme, M., Deguillaume, L., Guilbaud, C., Morris, C. E., et al. (2013). Ice nucleation activity of bacteria isolated from cloud water. Atmospheric Environment, 70, 392-400.

Joly, M., Amato, P., Sancelme, M., Vinatier, V., Abrantes, M., Deguillaume, L., Delort, A.-M. (2015). Survival of microbial isolates from clouds toward simulated atmospheric stress factors. Atmospheric Environment, doi:10.1016/j.atmosenv.2015.07.009

Jozefczuk, S., Klie, S., Catchpole, G., Szymanski, J., Cuadros-Inostroza, A., Steinhauser, D., et al. (2010). Metabolomic and transcriptomic stress response of Escherichia coli. Molecular Systems Biology, doi:10.1038/msb.2010.18

Kanehisa, M., Goto, S. (2000). KEGG: Kyoto Encyclopedia of Genes and Genomes. Nucleic Acids Research, 28, $27-$ 30 .

Kol, S., Merlo, M. E., Scheltema, R. A., de Vries, M., Vonk, R. J., Kikkert, N. A., et al. (2010). Metabolomic Characterization of the Salt Stress Response in Streptomyces coelicolor. Applied and Environmental Microbiology, 76, 2574-2581.

Kourtev, P. S., Hill, K. A., Shepson, P. B., Konopka, A. (2011). Atmospheric cloud water contains a diverse bacterial community. Atmospheric Environment, 45, 5399-5405.

Kuhl, C., Tautenhahn, R., Böttcher, C., Larson, T. R., Neumann, S. (2012). CAMERA: An Integrated Strategy for Compound Spectra Extraction and Annotation of Liquid Chromatography/ Mass Spectrometry Data Sets. Analytical Chemistry, 84(1), 283-289.

Kurz, M., Burch, Y. A., Seip, B., Lindow, S. E., Gross, H. (2010). Genome driven investigation of compatible solute biosynthesis pathway of Pseudomonas syringae pv syringae and their contribution to water stress tolerance. Applied and Environmental Microbiology, 76, 5452-5462.

Le Marrec, C., Bon, E., Lonvaud-Funel, A. (2007). Tolerance to high osmolality of the lactic acid bacterium Oenococcus oeni and identification of potential osmoprotectants. International Journal of Food Microbiology, 115, $335-42$.

Lin, C. Y., Wu, H., Tjeerdema, R. S., Viant, M. R. (2007). Evaluation of metabolite extraction strategies from tissue samples using NMR metabolomics. Metabolomics, 3, 55-67.

Miranda, H., Cheregi, O., Netotea, S., Hvidsten, T. R., Moritz, T., Funk, C. (2013). Co-expression analysis, proteomic and metabolomic study on the impact of a Deg/HtrA protease triple mutant in Synechocystis sp. PCC 6803 exposed to temperature and high light stress. Journal of Proteomics, 78, 294-311.

Nicholson, J. K., Foxall, P. J., Spraul, M., Farrant, R. D., Lindon, J. C. (1995). $750 \mathrm{MHz}{ }^{1} \mathrm{H}$ and ${ }^{1} \mathrm{H}-{ }^{13} \mathrm{C}$ NMR spectroscopy of human blood plasma. Analytical Chemistry, 67(5), 793-811.

Piuri, M., Sanchez-Rivas, C., Ruzal, S. M. (2003). Adaptation to high salt in Lactobacillus: role of peptides and proteolytic enzymes. Journal of Applied Microbiology, 95,372-9. 
Rabinowitz, J. D., Kimball, E. (2007). Acidic Acetonitrile for Cellular Metabolome Extraction from Escherichia coli. Analytical Chemistry, 79, 6167-6173.

Renard, P., Canet, I., Sancelme, M., Wirgot, N., Deguillaume, L., Delort, A.-M. (2016). Screening of cloud microorganisms isolated at the Puy de Dôme (France) station for the production of biosurfactants, Atmospheric Chemistry and Physics, doi:10.5194/acp-16-12347-2016

Sagot, B., Gaysinski, M., Mehiri, M., Guigonis, J. M., Le Rudulier, D., Alloing, G. (2010). Osmotically induced synthesis of the dipeptide $\mathrm{N}$-acetylglutaminylglutamine amide is mediated by a new pathway conserved among bacteria. Proceedings of the National Academy of Sciences, doi:10.1073/ pnas.1003063107

437 (2013). Hailstones: A Window into the Microbial and Chemical Inventory of a Storm Cloud. PLoS One, doi:10.1371/journal.pone.0053550

Sardesai, N., Babu, C. R. (2000). Cold stress induces switchover of respiratory pathway to lactate glycolysis in psychrotrophic Rhizobium strains. Folia Microbiologica, doi:10.1007/BF02817420

Sattler, B., Puxbaum, H., Psenner, R. (2001). Bacterial growth in supercooled cloud droplets. Geophysical Research Letters, 28, 239-242.

Shin, M. H., Lee, D. Y., Liu, K.-H., Fiehn, O., Kim, K. H. (2010). Evaluation of Sampling and Extraction Methodologies for the Global Metabolic Profiling of Saccharophagus degradans. Analytical Chemistry, 82, 66606666.

Shivaji, S., Prakash, J. S. (2010). How do bacteria sense and respond to low temperature? Archives of Microbiology, 192, 85-95.

Singh, A. K., Ulanov, A. V., Li, Z., Jayaswal, R. K., Wilkinson, B. J. (2011). Metabolomes of the psychrotolerant bacterium Listeria monocytogenes $10403 \mathrm{~S}$ grown at $37^{\circ} \mathrm{C}$ and $8^{\circ} \mathrm{C}$. International Journal of Food Microbiology, $148,107-14$.

Smith, L. T., Smith, G. M. (1989). An osmoregulated dipeptide in stressed Rhizobium meliloti. Journal of Bacteriology, doi:10.1128/jb.171.9.4714-4717.1989

Smith, C. A., O'Maille, G., Want, E. J., Qin, C., Trauger, S. A., Brandon, T. R., et al. (2005). METLIN: a metabolite mass spectral database. Therapeutic Drug Monitoring, 27(6), 747-751.

Smith, C. A., Want, E. J., O'Maille, G., Abagyan, R., Siuzdak, G. (2006). XCMS: Processing Mass Spectrometry Data for Metabolite Profiling Using Nonlinear Peak Alignment, Matching, and Identification. Analytical Chemistry, 78, 779-787.

Sumner, L. W., Amberg, A., Barrett, D., Beale, M. H., Beger, R., Daykin, C. A., et al. (2007). Proposed minimum reporting standards for chemical analysis. Metabolomics, 3, 211-221.

Sumner, L. W., Lei, Z. , Nikolau, B. J. , Saito, K., Roessner, U., Trengove, R. (2014). Proposed quantitative and alphanumeric metabolite identification metrics. Metabolomics, 10, 1047-1049.

Vaïtilingom, M., Charbouillot, T., Deguillaume, L., Maisonobe, R., Parazols, M., Amato, et al. (2011). Atmospheric chemistry of carboxylic acids: microbial implication versus photochemistry. Atmospheric Chemistry and Physics, 11, 8721-8733.

Vaïtilingom, M., Attard, E., Gaiani, N., Sancelme, M., Deguillaume, L., Flossmann, A. I., et al. (2012). Long-term features of cloud microbiology at the puy de Dôme (France). Atmospheric Environment, 56, 88-100.

Vaïtilingom, M., Deguillaume, L., Vinatier, V., Sancelme, M., Amato, P., Chaumerliac, N., Delort, A.-M. (2013). Potential impact of microbial activity on the oxidant capacity and organic carbon budget in clouds. Proceedings of the National Academy of Sciences, 110 (2), 559-564.

Welsh, D. T. (2000). Ecological significance of compatible solute accumulation by micro-organisms: from single cells to global climate. FEMS Microbiology Reviews, doi:10.1111/j. 1574-6976.2000.tb00542.x

Wishart, D. S., Jewison, T., Guo, A. C., Wilson, M., Knox, C., Liu, Y., et al. (2013). HMDB 3.0-The Human Metabolome Database in 2013. Nucleic Acids Research, 41(D1), D801-D807.

Ye, Y., Zhang, L., Hao, F., Zhang, J., Wang, Y., Tang, H. (2012). Global metabolomic responses of Escherichia coli to heat stress. Journal of Proteome Research, 11, 2559-66.

Zaprasis, A., Brill, J., Thüring, M., Wünsche, G., Heun, M., Barzantny, H., et al. (2013). Osmoprotection of Bacillus subtilis through import and proteolysis of pro-line-containing peptides. Applied and Environmental Microbiology, doi:10.1128/AEM.01934-12

Zhang, J., Li, Y., Chen, W., Du, G. C., Chen, J. (2012). Glutathione improves the cold resistance of Lacotococcus sanfranciscensis by physiological regulation. Food Microbiology, 31, 285-292.

483 


\section{Figure legends}

Fig. 1 a) Score plot from the PLS-DA of Pareto scaled LC-MS data (PC1 vs PC2 model). Blue triangles and red dots are from extracts of bacteria incubated at $5{ }^{\circ} \mathrm{C}$ and $17{ }^{\circ} \mathrm{C}$, respectively. In one group $\left(5^{\circ} \mathrm{C}\right)$, one sample is considered as an outlier (out of Hotelling ellipse). b) Score plot from PLS-DA of Pareto scaled NMR data (PC1 vs PC2 model).

Fig. 2 Metabolic pathways (carbohydrates, amino-acids, lipids and peptides) impacted by exposure of Pseudomonas syringae to cold shock. Metabolites that are overproduced at $5{ }^{\circ} \mathrm{C}$ are in yellow, and metabolites that are underproduced are in blue. Putative intermediates are indicated in white.

499

Fig. 3 Metabolic pathways of Pseudomonas syringae (glutathione, ornithine and lysine) impacted by exposure to cold. Metabolites that are overrepresented at $5{ }^{\circ} \mathrm{C}$ compared with $17{ }^{\circ} \mathrm{C}$ are in yellow, and metabolites that are underrepresented are in blue. Putative intermediates are indicated in white. 
Table 1: Identification criteria for metabolites considering MS and NMR experiments, and according to relevant 502 databases (or standard when mentioned). MS experiments: TOF, accurate mass measurement on LC-ToF (Time of Flight); HRMS, accurate mass measurement on LC-Orbitrap; MS/MS, fragmentation pattern on LC-Orbitrap; STD, comparison using pure chemical standard (at least parent ion mass and retention time). NMR experiments (validation mark for at least one result in the following experiment): ${ }^{1} \mathrm{H}$, chemical shift on proton NMR experiment; Jres, chemical shift and coupling constant on J-resolved experiment; COSY, chemical shift and correlation on COrrelation SpectrocopY experiment; TOCSY, chemical shift and correlation on TOtal Correlation SpectroscopY experiment; HSQC, chemical shift and correlation on Heteronuclear Single Quantum Correlation experiment

\begin{tabular}{|c|c|c|c|c|c|c|c|c|c|}
\hline \multirow[b]{2}{*}{ Identification status } & \multicolumn{4}{|c|}{ MS EXPERIMENTS } & \multicolumn{5}{|c|}{ NMR EXPERIMENTS } \\
\hline & TOF & HRMS & $\mathrm{MS} / \mathrm{MS}$ & STD & ${ }^{1} \mathrm{H}$ & Jres & COSY & TOCSY & HSQC \\
\hline $\begin{array}{c}\text { 5'-Deoxy-5'- } \\
\text { (methylthio)adenosine }\end{array}$ & $x$ & $x$ & $x$ & & & & & & \\
\hline Acetate & & & & & $x$ & & & & $x$ \\
\hline Alanine & $x$ & & & & $x$ & $\mathrm{x}$ & $\mathrm{x}$ & $\mathrm{x}$ & $\mathrm{x}$ \\
\hline Alanyl-Arginine & & $\mathrm{x}$ & $\mathrm{x}$ & $\mathrm{x}$ & & & & & \\
\hline Alanyl-Leucine & & $x$ & $x$ & $x$ & & & & & \\
\hline AMP & $\mathrm{x}$ & & & $x$ & & & $x$ & & $\mathrm{x}$ \\
\hline ATP & & & & & & & $x$ & & \\
\hline Bellendine & $x$ & & & & & & & & \\
\hline Carnitine & $x$ & $\mathrm{x}$ & & & & & & & \\
\hline Feruloylputrescine & $x$ & & & & & & & & \\
\hline Gln-Ser-Ala-Gln & & $x$ & $x$ & & & & & & \\
\hline Glutamate & $\mathrm{x}$ & & & $\mathrm{x}$ & $\mathrm{x}$ & $\mathrm{x}$ & $\mathrm{x}$ & & $\mathrm{x}$ \\
\hline Glutamyl-Alanine & & $\mathrm{x}$ & $\mathrm{x}$ & $x$ & & & & & \\
\hline Glutathione & $x$ & & & & $x$ & $x$ & $x$ & $x$ & $x$ \\
\hline Glycerol & & & & & $x$ & $x$ & $x$ & $\mathrm{x}$ & $x$ \\
\hline Glycine & & & & & $x$ & & & & $x$ \\
\hline Glycogen & & & & & $x$ & $x$ & $x$ & $x$ & $x$ \\
\hline Gyromitrin & $\mathrm{x}$ & & & & & & & & \\
\hline Isoleucine & $X^{1}$ & & & & $x$ & $x$ & $x$ & & $x$ \\
\hline Lactate & & & & & $x$ & $x$ & $x$ & & $x$ \\
\hline Leucine & $X^{1}$ & & & & $x$ & $x$ & $x$ & $x$ & $x$ \\
\hline Leucyl-leucine & $x$ & & & $x$ & & & & & \\
\hline Leucyl-Phenylalanine & $\mathrm{X}$ & & & $\mathrm{X}$ & & & & & \\
\hline Lysine & $x$ & $x$ & & & $x$ & $x$ & $x$ & $x$ & $\mathrm{x}$ \\
\hline LysoPC(16:1) & $x$ & & & & & & & & \\
\hline LysoPE $16: 0$ & $x$ & & & $x$ & & & & & \\
\hline LysoPE $18: 1$ & $x$ & & & $x$ & & & & & \\
\hline LysoPE(0:0/16:1(9Z)) & $x$ & & & & & & & & \\
\hline Methionine & $x$ & & & & $x$ & $x$ & $x$ & $x$ & $x$ \\
\hline Oleic acid & $x$ & & & & & & & & \\
\hline O-phosphocholine & & & & & $x$ & & & & $x$ \\
\hline Palmitoleic acid & $x$ & & & $x$ & & & & & \\
\hline PE(P-16:0e/0:0) & $x$ & & & & & & & & \\
\hline Phenylalanine & $x$ & $x$ & & $x$ & $x$ & $x$ & $\mathrm{x}$ & & $x$ \\
\hline
\end{tabular}




\begin{tabular}{|c|c|c|c|c|c|c|c|c|c|}
\hline Phosphoric acid & $X$ & $\mathrm{X}$ & & & & & & & \\
\hline Piperidine & $x$ & & & $x$ & & & & & \\
\hline Proline-(iso)Leucine & & $x$ & $x$ & $x$ & & & & & \\
\hline Proline-Phenylalanine & $x$ & & & & & & & & \\
\hline Putrescine & $x$ & & & $x$ & & & $x$ & $x$ & $x$ \\
\hline Sarcosine & $x$ & & & & & & & & \\
\hline Serine-Valine & & $x$ & $x$ & $x$ & & & & & \\
\hline Slaframine & $x$ & & & & & & & & \\
\hline Trehalose & & & & & $x$ & $x$ & $X$ & $x$ & $X$ \\
\hline Tyrosine & & & & & $\mathrm{X}$ & $x$ & $x$ & & $\mathrm{X}$ \\
\hline Valine & & & & & $x$ & $x$ & $x$ & & $x$ \\
\hline Valine-Valine & & $x$ & $x$ & $x$ & & & & & \\
\hline$\alpha$-Glucose & & & & & $x$ & $x$ & $x$ & $x$ & $x$ \\
\hline$\beta$-Glucose & & & & & $\mathrm{X}$ & $x$ & $x$ & $x$ & $\mathrm{X}$ \\
\hline
\end{tabular}

${ }^{1}$ MS data do not permit to differentiate leucine and isoleucine. 
511 Table 2: Identified metabolites according to MS and NMR experiments. All metabolites presented here are key 512 biomarkers dicriminating the two bacterial populations incubated at $5^{\circ} \mathrm{C}$ (stress) and $17^{\circ} \mathrm{C}$ (reference). Statistical 513 model provide a VIP value of metabolites' influence for each analytical technique. S/R (stress/reference) ratio 514 represents the ratio of the means relative intensities measured on MS or NMR profiles of a given metabolite in cells 515 incubated at $5{ }^{\circ} \mathrm{C}$ vs at $17^{\circ} \mathrm{C}$.

\begin{tabular}{|c|c|c|c|c|c|}
\hline \multirow{2}{*}{$\begin{array}{l}\text { Identified } \\
\text { VIP } \\
\text { Metabolites }\end{array}$} & \multicolumn{2}{|c|}{ MS } & \multicolumn{2}{|c|}{ NMR } & \multirow{2}{*}{$\frac{\text { ID metrics }}{*}$} \\
\hline & VIP score & S/R Ratio & VIP score & S/R Ratio & \\
\hline \multicolumn{6}{|c|}{ Amino acids } \\
\hline Valine & & & $2.17-2.49$ & 0.49 & II (5) \\
\hline Leucine & 2011 & 0501 & 3.38 & 0.51 & II (9) \\
\hline Isoleucine & 3.91 & 0.59 & $1.99-2.19$ & $0.38-0.5$ & II (5) \\
\hline Alanine & 1.42 & 0.58 & $1.34-1.68$ & $0.77-0.83$ & II (10) \\
\hline L-Lysine & $2.76^{2}$ & $0.42^{2}$ & $1.18-1.49$ & $0.72-0.77$ & II (10) \\
\hline Phenylalanine & 2.91 & 0.53 & $1.09-1.37$ & $0.72-0.74$ & I \\
\hline Tyrosine & & & $1.03-1.08$ & $0.49-0.52$ & II (5) \\
\hline Methionine & 1.71 & 0.52 & $1.32-1.49$ & $0.79-0.8$ & II (10) \\
\hline Sarcosine & 1.62 & 0.52 & & & III (1) \\
\hline L-Glutamate & $1.22^{2}$ & $1.18^{2}$ & $1.41-1.75$ & $\mathrm{ND}^{*}$ & I \\
\hline Glycine & & & 1.01 & $1.09 *$ & II (2) \\
\hline \multicolumn{6}{|c|}{ Saccharides } \\
\hline Glucose & & & $1.04-1.32$ & $1.39-1.59$ & II (9) \\
\hline Trehalose & & & $5.42-6.06$ & 2.5 & II (9) \\
\hline Glycogen & & & $1.13-1.44$ & $0.75-0.85$ & II (9) \\
\hline \multicolumn{6}{|c|}{ Amines } \\
\hline Putrescine & 2.05 & 0.46 & $1.57-1.80$ & $0.51-0.54$ & I \\
\hline Feruloylputrescine & 1.64 & 0.28 & & & III (1) \\
\hline Piperidine & 3.41 & 0.5 & & & I \\
\hline Carnitine & 1.62 & 2.38 & & & III (1) \\
\hline \multicolumn{6}{|c|}{ Lipids } \\
\hline Palmitoleic acid & 4.20 & 0.26 & & & I \\
\hline Oleic acid & 2.48 & 0.44 & & & III (1) \\
\hline LysoPE $18: 1$ & 3.04 & 0.3 & & & I \\
\hline O-phosphocholine & & & 1.16 & $0.78 *$ & II (2) \\
\hline LysoPE(0:0/16:1(9Z)) & 1.03 & 0.74 & & & III (1) \\
\hline LysoPE 16:0 & 2.43 & 0.4 & & & I \\
\hline LysoPC 16:1 & 1.66 & 0.37 & & & III (1) \\
\hline PE(P-16:0e/0:0) & 1.21 & 0.65 & & & III (1) \\
\hline
\end{tabular}

Miscellaneous 


\begin{tabular}{|c|c|c|c|c|c|}
\hline Slaframine & 1.78 & 0.11 & & & III (1) \\
\hline Acetate & & & $1.01-1.28$ & $0.72-0.78$ & II (2) \\
\hline Lactate & & & $1.76-2.04$ & $0.67-0.78$ & II (5) \\
\hline AMP & 1.49 & 1.28 & 1.03 & 1.11 & I \\
\hline ATP & & & $1.02-1.26$ & $1.11-1.25$ & II (5) \\
\hline Phosphoric acid & 1.42 & 1.45 & & & III (1) \\
\hline Glycerol & & & 4.40 & $1.45^{*}$ & II (9) \\
\hline Gyromitrin & 1.02 & 1.2 & & & III (1) \\
\hline Bellendine & 1.71 & 3.7 & & & III (1) \\
\hline Glutathione & 5.71 & 2 & $1.45-1.90$ & $1.27-1.59$ & II (10) \\
\hline $5^{6}$-Deoxy-5'-(methylthio)adenosine & 1.09 & 2.5 & & & II $(2.5)$ \\
\hline \multicolumn{6}{|c|}{ Peptides } \\
\hline Alanyl-leucine & 2.78 & 0.35 & & & I \\
\hline Leucyl-leucine & 2.76 & 0.27 & & & I \\
\hline Alanyl-arginine & 2.11 & 0.22 & & & I \\
\hline Leucyl-phenylalanine & 1.72 & 0.3 & & & I \\
\hline Glutamyl-alanine & 1.61 & 0.44 & & & I \\
\hline Prolyl-phenylalanine & 1.40 & 0.22 & & & III (1) \\
\hline Prolyl-(iso)leucine & 1.37 & 0.22 & & & I \\
\hline Valyl-valine & 1.06 & 0.33 & & & I \\
\hline Seryl-valine & 1.34 & 1.75 & & & I \\
\hline Gln-Ser-Ala-Gln & 1.1 & 5.88 & & & II (3) \\
\hline
\end{tabular}

$517{ }^{1}$ not differentiable through MS experiments; ${ }^{2}$ information about L/D conformation is not available through MS 518 experiments; * quantifications are given according to ${ }^{1} \mathrm{H}-\mathrm{NMR}$ buckets with peak overlaps. ** Classes and scores are 519 according to Sumner et al. (2007; 2014; See Table S1). 